\title{
The Analysis of Factors Affecting Income Level of Street Vendors
}

\author{
By: \\ Indah Setyaningsih ${ }^{1)}$, Sukiman ${ }^{1)}$, Neni Widayaningsih ${ }^{1 *}$ \\ ${ }^{1)}$ Faculty of Economics and Business, Jenderal Soedirman University \\ ${ }^{*}$ Corresponding Author: nenipriyono@gmail.com
}

Submission: 16 April 2019, Accepted: 20 June 2019

\begin{abstract}
This study aims to analyze the income level of the family of street vendors obtained from selling foods and beverages at tourist attraction of Suwuk Beach, Kebumen Regency. There are many studies on the examine the factors affecting income level of street vendors in developing countries. However, some of the previous studies have not included demographic variables such as role of female workers in informal sector and attained level of education by the owner. This study analyzes variables such as business initial capital, education level, gender, length of business, and number of workers in affecting the street vendor's income. This study uses 53 respondents as source of data. Cross-section analysis is used as the analytical tool. Estimation results shows that business initial capital, number of workers, and length of business has significant effect on the street vendor's income. While gender and education level has no significant effect on street vendor's income.
\end{abstract}

Keywords: Family Business, Street Vendor, Tourism.

\begin{abstract}
ABSTRAK
Penelitian ini bertujuan untuk menganalisis tingkat pendapatan keluarga pedagang kaki lima yang diperoleh dari menjual makanan dan minuman di daerah wisata Pantai Suwuk, Kabupaten Kebumen. Ada banyak penelitian yang meneliti faktor-faktor yang mempengaruhi tingkat pendapatan pedagang kaki lima di negara yang sedang berkembang. Namun demikian, sebagina dari penelitian terdahulu tersebut belum memasukan variabel-variabel demografi seperti jenis kelamin dan tingkat pendidikan yang ditempuh oleh pemilik usaha. Studi ini menganalisa hubungan antara modal usaha, tingkat pendidikan, jenis kelamin, lama usaha, dan jumlah tenaga kerja dengan pendapatan pedagang kaki lima. Peneltian ini menggunakan data yang diperoleh dari 53 responden. Alat analisis yang kami gunakan adalah analisis cross section. Hasil estimasi kami menunjukkan bahwa terdapat hubungan yang kuat antara besanya modal awal usaha, jumlah tenaga kerja, dan lamanya usaha dengan pendapatan usaha. Sementara jenis kelamin dan tingkat pendidikan tidak signifikan dalam mempengaruhi besarnya pendapatan usaha.
\end{abstract}

Kata Kunci: Bisnis Keluarga, Pedagang Kaki Lima, Pariwisata. 
The Analysis of Factors .... (Setyaningsih, et al.)

\section{INTRODUCTION}

Data from the Indonesian Ministry of Tourism shows that in 2016 the tourism sector tourism $(12,225.89$ million USD) was the fourth largest foreign exchange earner after oil and gas $(18,552.10$ million USD), coal (15,943.00 million USD), palm oil (15,385.20 million USD). However, the most important thing about the development of the tourism sector is the ability to have a positive impact on Indonesian people in order to open jobs and improve people's welfare.

Kebumen is a regency in Indonesia with tourism potential. Tourism Development Master Plan of Central Java Province for 2012-2027 article 10 paragraph 1, included Kebumen Regency as Central Java Provincial Tourism Development Zone (Kawasan Pengembangan Pariwisata Provinsi or KPPP). Thus, the regency has the opportunity to obtain economic benefits from the regional tourism sector development plan.

Table 1 shows the amount of income from the tourism in Kebumen Regency from 2011 to 2016. Regional Income of Kebumen Regency that came from the tourism sector continue to increase since 2011, with the highest growth was in 2012 where there is 38.18 percent increase in regional income compared to previous year.

Table 1. Regional Income from Tourism in Kebumen Regency from 2011-2016

\begin{tabular}{ccc}
\hline Year & Regional Income (Rp) & Growth (\%) \\
\hline 2011 & $3,037,465,210$ & - \\
2012 & $4,197,398,375$ & 38.18 \\
2013 & $4,372,954,050$ & 4.18 \\
2014 & $5,067,553,875$ & 15.89 \\
2015 & $5,653,204,994$ & 11.56 \\
2016 & $5,844,464,245$ & 3.38 \\
\hline
\end{tabular}

Source: Disporawisata of Kebumen Regency, 2017.

Local government in Kebumen Regency currently manages nine tourist attractions. Of the nine tourist attractions, Suwuk Beach is the most visited tourist attraction compared to other. As seen in Table 2, during 2011 to 1015 the number of tourists who visited Suwuk Beach have increased and also it shows that in the 2015 Suwuk Beach is the most favored destination in Kebumen Regency.

Table 2. Number of tourists visiting Tourist Attractions in Kebumen Regency from 2011-2016

\begin{tabular}{|c|c|c|c|c|c|c|}
\hline \multirow{2}{*}{ No } & \multirow{2}{*}{ Tourist Attraction } & \multicolumn{5}{|c|}{ Number of Tourists (visitors) } \\
\hline & & 2011 & 2012 & 2013 & 2014 & 2015 \\
\hline 1 & Jatijajar Cave & 257,304 & 280,926 & $281 ., 239$ & 297,682 & 322,936 \\
\hline 2 & Logending Beach & 122,540 & 121,521 & 113,090 & 123,115 & 125,310 \\
\hline 3 & Petruk Cave & 8,239 & 10,570 & 9,723 & 9,830 & 9,876 \\
\hline 4 & Karangbolong Beach & 18,221 & 20,967 & 21,164 & 24,104 & 26,884 \\
\hline 5 & Petanahan Beach & 77,945 & 85,657 & 86,935 & 81,996 & 90,668 \\
\hline 6 & Sempor Reservoir & 28,150 & 28,415 & 25,220 & 34,756 & 34,951 \\
\hline 7 & Krakal Hot Water Bath & 17,841 & 19,244 & 20,064 & 22,506 & 24,822 \\
\hline 8 & Wadaslintang Reservoir & 27,511 & 30,714 & 20,834 & 22,381 & 27,056 \\
\hline 9 & Suwuk Beach & 144,152 & 209,671 & 227,350 & 340,637 & 454,633 \\
\hline & Total & 701,903 & 807,685 & 805,619 & 957,007 & $1,117,151$ \\
\hline
\end{tabular}

Source: Disporawisata of Kebumen Regency, 2017.

The increasing number of tourists on Suwuk Beach is inseparable from the participation of the local government in Kebumen Regency. Since 2011, the local government has made enormous efforts to improve tourist attraction in Suwuk Beach, especially for supporting facilities such as construction and repair of roads, construction of entry gate to tourist attractions, construction of parking area, arrangement and construction of kiosks, and construction of prayer room and toilets. Local 
government also built swimming pool and educational cinema. So, with the supporting action from the local government of Kebumen Regency it is expected to increase the economic potential of tourist attraction at Suwuk Beach, and that the surrounding community could be able to participate and gain the economic benefits from it.

Most local community business operating at tourist attraction sites in Indonesia are small traders (informal sector), namely street vendors. Based on data from the Ministry of Cooperative and MSMEs of the Republic of Indonesia, this sector in 2017 has contributed to Indonesia's GDP by 30 percent and absorbed 89.7 percent of the labor force. This phenomenon is commonly found in economies of developing countries. In fact, according to Adhikari (2011), the informal sector in developing countries is estimated to absorb two-thirds of the total available labor force and contributes one-third of the national GDP, especially in the agricultural sector. Due to the large absorptive capacity of the labor force and its high contribution to national GDP, the government sometime pays high attention to this informal sector.

However, besides absorbing most of the labor force, the existence of informal sector comes with an irony. The existence of the informal sectors such as street vendors are a manifestation of urban poverty that often found in developing countries and this business is very popular with the poor because it is one way to obtain relatively easy income with minimum capital (Adhikari, 2017).

According to data of Central Statistics Agency of Central Java Province, Kebumen Regency was ranked as the second poorest regency in Central Java in 2018. The expected outcome from the inclusion of Kebumen Regency in the 2012-2027 Tourism Development Master Plan of Central Java Province is that the communities around the tourist attractions in Kebumen Regency can obtain economic benefits that could help reduce poverty in this region.

As described earlier, it tells that Suwuk Beach has great potential in providing employment and can improve welfare for the community around the tourist attraction. Based on interview with the manager of Suwuk Beach Tourism, that after being revitalized the livelihood of local community become varies. Previously, almost 70 percent of the local community surrounding Suwuk Beach work as fishermen and farmers, but today there are many. Some of them opening small business as street vendors, some rent his/her house for inn, and some open a small store selling food and drinks. In this study, we want to highlight the street vendor business that operated in Suwuk Beach and analyze the income level of the family of street vendors obtained from selling foods and beverages at tourist attraction.

There are some literature on the factors affecting income level of street vendors in developing countries. A study conducted by Adhikari (2017) found that capital, number of workers and education level of street vendors had a significant effect on income level of street vendors in Nepal. Meanwhile Harahap (2017) conducted a study on the factors affecting the income of street vendors in Padang after the earthquake in 2009 that left many residents of the city losing their jobs and turning to the informal sector. He found that variables such as turnover, working capital, and operational costs significantly affect the income of the street vendors in Padang. Another study conducted by Antara and Aswitari (2016) found that the income of street vendors in West Denpasar Sub-District was affected by business capital, number of workers, and length of business.

Nevertheless, the previous studies on street vendors businesses seldom included social and demographic variables such as role of female workers in informal sector and business's owner level of education. The role of female workers in the informal sector in countries with tradition, culture, and trust is highly important according to Otto et al (2011). For business owner level of education, it is very rare to discuss because many believe that Education level is often not quite influential on success in business management in the informal sector. According to Unger et al (2011), human capital in conducting business is useful only if it is applicable in doing some specific tasks for the business owner. He distinguished between task-related human capital and non-task-related human capital. For task related human capital, it is such as owner experience, start-up experience, industry experience, and entrepreneurial knowledge. Non- related task human capital is such as general education of business owners and employment experiences. He argues that human capital had effect on business, but the 
greatest effect was generated by human capital investment in skills (related-task human capital) compared than human capital investment in education or length of school year.

So, this study included the variable of gender and business owner education level of street vendors at Suwuk Beach on affecting their business income. Therefore, based on this description above, this study aimed to identify the factors affecting the income level of street vendors, especially food and beverage street vendors at Suwuk Beach, Kebumen Regency.

\section{METHOD}

This study used primary data which was obtained through questionnaire and surveys. In order to determine the number of the sample, our study use accidental sampling method. It is non-probability sampling method that taking sample from population who is close at hand. Our study use 53 street vendors selling foods and beverages at Suwuk Beach as the sample respondents. While the supporting data such as data on tourist attractions were obtained from the Central Statistics Agency of Kebumen Regency and the Tourism Department of Kebumen Regency.

The model used to analyze factors affecting the income of street vendors is as follows:

$$
Y_{i}=\alpha_{0}+\beta_{1} G d r_{i}+\beta_{2} \operatorname{Cap}_{i}+\beta_{3} \text { Worker }_{i}+\beta_{4} \operatorname{Exp}_{i}+\beta_{5} D 1_{i}+\beta_{6} D 2_{i}+\beta_{7} D 3_{i}+\beta_{8} D 4_{i}+\varepsilon
$$

Where $Y$ is the dependent variable of street vendor income, while the independent variable is GDR variable showing gender of street vendors, Cap is the variable of amount of business capital, Worker is the variable of number of workers, Exp is the variable of length of business, D1-4 is dummy variable of education level (elementary school D1, junior high school D2, senior high school D3, and not in school D4).

Table 3. Description of Variables.

\begin{tabular}{|c|c|c|c|}
\hline Variables & $\begin{array}{l}\text { Description of } \\
\text { Variables }\end{array}$ & Category & Measurement \\
\hline $\mathrm{Y}$ & $\begin{array}{l}\text { Owner's monthly } \\
\text { income from } \\
\text { conducting business. }\end{array}$ & Dependent variable & $\begin{array}{l}\text { It is monthly net income measured } \\
\text { by total monthly sales income } \\
\text { minus operating cost. }\end{array}$ \\
\hline $\mathrm{Gdr}_{\mathrm{i}}$ & $\begin{array}{l}\text { Dummy variables for } \\
\text { owner's gender. }\end{array}$ & Independent variable & $1=$ male $0=$ female \\
\hline $\mathrm{Cap}_{\mathrm{i}}$ & $\begin{array}{l}\text { Amount of initial } \\
\text { capital when the } \\
\text { owner starting } \\
\text { business. }\end{array}$ & Independent variable & $\begin{array}{l}\text { Amount of initial capital that is } \\
\text { invested by the owner in starting } \\
\text { business. }\end{array}$ \\
\hline Worker $_{i}$ & $\begin{array}{l}\text { Amount of labor } \\
\text { employed by the } \\
\text { owner. }\end{array}$ & Independent variable & $\begin{array}{l}\text { Amount of labor that is employed. It } \\
\text { includes the owners himself if he } \\
\text { run both as the owner of the } \\
\text { business and also worker, family } \\
\text { member who employed as worker, } \\
\text { and non-family worker who } \\
\text { recruited as worker by the owner. }\end{array}$ \\
\hline $\operatorname{Exp}_{i}$ & $\begin{array}{l}\text { Length of conducting } \\
\text { business. }\end{array}$ & Independent variable & $\begin{array}{l}\text { It is measured by how many years } \\
\text { the owner conducting business in } \\
\text { Suwuk Beach. }\end{array}$ \\
\hline $\mathrm{D}_{1 \mathrm{i}}$ & $\begin{array}{l}\text { Owner's level of } \\
\text { education if he } \\
\text { finished his or her } \\
\text { elementary school. }\end{array}$ & Independent variable & $\begin{array}{l}1=\text { finished elementary school } \\
0=\text { not finished elementary school }\end{array}$ \\
\hline
\end{tabular}




\begin{tabular}{|c|c|c|c|}
\hline Variables & $\begin{array}{l}\text { Description of } \\
\text { Variables }\end{array}$ & Category & Measurement \\
\hline$D_{2 i}$ & $\begin{array}{l}\text { Owner's level of } \\
\text { education if he } \\
\text { finished his or her } \\
\text { junior high school. }\end{array}$ & Independent variable & $\begin{array}{l}1=\text { finished junior high school, } \\
0=\text { not finished junior high school }\end{array}$ \\
\hline$D_{3 i}$ & $\begin{array}{l}\text { Owner's level of } \\
\text { education if he } \\
\text { finished his or her } \\
\text { senior high school or } \\
\text { go to college. }\end{array}$ & Independent variable & $\begin{array}{l}1=\text { finished senior high school or go } \\
\text { to the college } \\
0=\text { not finished either senior high } \\
\text { school nor college }\end{array}$ \\
\hline $\mathrm{D}_{4 \mathrm{i}}$ & $\begin{array}{l}\text { Owner's level of } \\
\text { education if he or she } \\
\text { is not complete any } \\
\text { formal education } \\
\text { level. }\end{array}$ & Independent variable & $\begin{array}{l}1=\text { not complete any formal } \\
\text { education. } \\
0=\text { complete any formal education. }\end{array}$ \\
\hline
\end{tabular}

The income variable uses net income of trading business after deducting costs. The gender variable is used in the equation to show differences in income between male street vendors and female street vendors. We expect that street vendor which is run by female will generate less income than is run by male owners. Male street vendors commonly have a higher income if compared to female street vendors. This is because male street vendors generally do not have the responsibility to work outside the business such as taking care of the household, so that male street vendors have more time to conduct trading business than female street vendors. Meanwhile, the variable of business capital is the initial capital or the amount of initial investment when the business owner establishes a trading business. The variable of number of workers is the number of people working as street vendors, including the business owner, family members, and people employed by the business owner. The variable of length of business is the length of business carried out by street vendors in pursuing their trading business on Suwuk Beach.

Amount of capital and number of workers are expected to have positive relationship with business net income as predicted by production theory. The variable of education level indicates the last education undertaken by business owner. The variable of education level is divided into four by using three dummy variables. Dummy 1 indicates education level of elementary school, Dummy 2 indicates education level of junior high school, Dummy 3 indicates education level of senior high school and tertiary education, while Dummy 4 indicates education level of zero or not in school. The model above is a cross section model and it is estimated using the OLS method.

\section{RESULT AND DISCUSSION}

Model estimation results of the income level of street vendors at Suwuk Beach, Kebumen Regency can be seen in Table 4. In order to determine the validity of the model, this study use two criteria there are adjusted R-squared and joint probability test (F-Test). From our estimation, the value of adjusted Rsquared is 0.49 . It means forty nine percent variability of owner's monthly income from conducting business could be explained by variability of independent variables. Second criteria is joint probability test using value of F-statistic. It shows that the value of F-statistic is 7.49 , so we reject null hypothesis that our coefficient equal to zero. 
The Analysis of Factors .... (Setyaningsih, et al.)

Table 4. Estimation Results of Factors Affecting Income Levels of Street Vendors at Suwuk Beach, Kebumen Regency

\begin{tabular}{lrll}
\hline \multicolumn{1}{c}{ Variables } & \multicolumn{2}{c}{ Coefficient } & \multicolumn{2}{c}{ Model Selection Criterion } \\
\hline Constant & 708538.2 & R-Squared & 0.57 \\
& $(1,32)$ & Adjusted R-Squared & 0.499 \\
Gdr & -166277.4 & F-statistic & 7.49 \\
& $(-0.61)$ & Prob (F-Statistic) & 0.000003 \\
Cap & 0.166673 & & \\
& $(3.24)^{* *}$ & & \\
Worker & 331330.2 & & \\
Exp & $(2.38)^{*}$ & & \\
& 91241.03 & & \\
D1 & $(3,70)^{* *}$ & & \\
& 374876.8 & & \\
D2 & $(1,02)$ & & \\
& 147660.5 & & \\
D3 & $(0,39)$ & & \\
& 80514.83 & & \\
D4 & $(0,21)$ & & \\
& -129902.1 & & \\
& $(-0,28)$ & & \\
\hline
\end{tabular}

Note: The values in parentheses are the values of t-statistics

*significant at $\alpha=5 \%$,

$* *$ significant at $\alpha=1 \%$.

In Table 4, the estimation results show that not all independent variables significantly affect the amount of street vendor income. Only the variables of initial capital, workers, and length of business have a significant effect on the income variable, while gender and education level variables do not have a significant effect on the income variable.

In theory, the amount of initial capital will certainly affect the income level of street vendors because this is one of production factors. However, trading activities and starting a business in the informal sector do not require large capital. Table 5 shows the amount of initial capital distribution of the respondents.

Table 5. Initial Capital Distribution of Street Vendor Samples at Suwuk Beach, Kebumen Regency

\begin{tabular}{ccccc}
\hline $\begin{array}{c}\text { Initial Capital } \\
(\text { Rp) }\end{array}$ & $\begin{array}{c}\text { Amount of Street } \\
\text { Vendor (Unit) }\end{array}$ & $\begin{array}{c}\text { Percentage } \\
(\%)\end{array}$ & $\begin{array}{c}\text { Cumulative Amount of } \\
\text { Street Vendor (Unit) }\end{array}$ & $\begin{array}{c}\text { Cumulative Percentage } \\
(\%)\end{array}$ \\
\hline $1,500,000$ & 1 & 1.89 & 1 & 1.89 \\
$2,000,000$ & 9 & 16.98 & 10 & 18.87 \\
$2,500,000$ & 4 & 7.55 & 14 & 26.42 \\
$3,000,000$ & 10 & 18.87 & 24 & 45.28 \\
$3,500,000$ & 6 & 11.32 & 30 & 56.60 \\
$4,000,000$ & 7 & 13.21 & 37 & 69.81 \\
$4,500,000$ & 2 & 3.77 & 39 & 73.58 \\
$5,000,000$ & 5 & 9.43 & 44 & 83.02 \\
$5,500,000$ & 1 & 1.89 & 45 & 84.91 \\
$6,000,000$ & 1 & 1.89 & 46 & 86.79 \\
$7,000,000$ & 1 & 1.89 & 47 & 88.68 \\
$7,500,000$ & 1 & 1.89 & 48 & 90.57 \\
$8,000,000$ & 1 & 1.89 & 49 & 92.45 \\
$8,500,000$ & 1 & 1.89 & 50 & 94.34 \\
\hline
\end{tabular}




\begin{tabular}{ccccc}
\hline $\begin{array}{c}\text { Initial Capital } \\
(\mathrm{Rp})\end{array}$ & $\begin{array}{c}\text { Amount of Street } \\
\text { Vendor (Unit) }\end{array}$ & $\begin{array}{c}\text { Percentage } \\
(\%)\end{array}$ & $\begin{array}{c}\text { Cumulative Amount of } \\
\text { Street Vendor (Unit) }\end{array}$ & $\begin{array}{c}\text { Cumulative Percentage } \\
(\%)\end{array}$ \\
\hline $9,000,000$ & 1 & 1.89 & 51 & 96.23 \\
$9,500,000$ & 1 & 1.89 & 52 & 98.11 \\
$10,000,000$ & 1 & 1.89 & 53 & 100.00 \\
\hline Total & 53 & 100.00 & 53 & 100.00 \\
\hline
\end{tabular}

More than half of street vendors use initial capital for businesses of less than Rp3,500,000. The low capital needed for businesses in this sector as described in the previous section is a manifestation of poverty in the urban area. The informal sector is in demand because it requires minimum capital to generate income for the business owner. Likewise with consumers, the presence of street vendors selling low cost foods and beverages is in demand by consumers with low purchasing power in the urban area (Tedd et al, 2001). In addition, the coefficient value of Cap variable (initial capital) is 0.166673. This means that if the street vendor makes an investment or adds an initial capital of 10 million rupiah, the average expected income to be obtained is $\mathrm{Rp} 1,666,730.00$ per month. The problem is that the informal sector businesses, especially the street vendors, have limited access to capital that can hinder their income. This can be seen from the estimation results that assumed holding other thing constant, it can interpreted that the additional capital is able to provide additional average income of 16.6 percent per month for street vendors. In this case, the local government can play a role in providing capital assistance or soft loan to street vendors to increase their net income.

The variable of number of workers also has an effect on the income of street vendors. Workers can have a good effect on the production function (as a production factor) to increase output and income, but they also belong to the cost function. The distribution of workers data of street vendors can be seen Table 6.

As shown in Table 6, the majority of street vendors (73.58\%) employ two workers to operate the trading business. The informal sector does not require a high number of workers, even the business owners in the informal sector act as workers, so that this dual role makes labor cost relatively low. From the observation results in the field, street vendors employing more than one worker are mostly assisted by their family members either the wife, husband, or children. Employing family members as workers can reduce wage cost for workers of the street vendors. While seeing from the coefficient value of number of workers from the estimation model of income level of street vendors, it indicates that the addition of one worker can increase net income of the business by Rp331,330. However, this result need to be carefully looked at, because the majority of workers in the samples of this study are the business owner's family members. This result can be used when the business owner's family members have not worked and are not highly educated. They can work in the informal sector or the family business in this sector while waiting for better employment opportunities because the characteristics of the labor market in this sector indicate a high turnover of workers (Ulyssea, 2010).

Table 6. Number of Workers of Street Vendors at Suwuk Beach, Kebumen Regency

\begin{tabular}{ccccc}
\hline $\begin{array}{c}\text { Worker } \\
\text { (Person) }\end{array}$ & $\begin{array}{c}\text { Amount of Street } \\
\text { Vendors (Unit) }\end{array}$ & $\begin{array}{c}\text { Percentage } \\
(\%)\end{array}$ & $\begin{array}{c}\text { Acumulative Amount of } \\
\text { Street Vendors (Unit) }\end{array}$ & $\begin{array}{c}\text { Acumulative Percentage } \\
(\%)\end{array}$ \\
\hline 1 & 10 & 18.87 & 10 & 18.87 \\
2 & 29 & 54.72 & 39 & 73.58 \\
3 & 13 & 24.53 & 52 & 98.11 \\
4 & 1 & 1.89 & 53 & 100.00 \\
\hline Total & 53 & 100.00 & 53 & 100.00 \\
\hline
\end{tabular}

Length of business is one of the variables that has a significant effect on the income level of street vendors. The result of regression coefficient indicated that there is a positive relationship between length of business and net income level of traders. This means that the longer they run a trading business, the greater their net income. In addition to improving trading experience and skills, 
the length of business indicates trader's survivability in a market. Businesses that can survive in a market can be said to have been efficient and inefficient businesses is unable to compete and will eventually leave the market. The leaving of business competitors from this market can increase the market share of the surviving businesses. This can be seen from the majority of respondents in this study had been running trading business at the tourist attraction of Suwuk Beach for approximately six years (see Table 7).

Table 7. Length of Business of Street Vendors at Tourist Attraction of Suwuk Beach, Kebumen Regency

\begin{tabular}{lcc}
\hline \multicolumn{1}{c}{ Length of Business } & Number of Street Vendors & Percentage \\
\hline $1-3$ years & 11 & 20.75 \\
$4-6$ years & 11 & 20.75 \\
$7-9$ years & 13 & 24.53 \\
\hline $10-12$ years & 12 & 22.64 \\
$13-15$ year & 5 & 9.44 \\
$>15$ years & 1 & 1.89 \\
\hline
\end{tabular}

Table 7 shows that the number of street vendors with length of business of less than four years is only 11 street vendors, the remaining are street vendors with length of business of more than four years. With length of business of more than four years, street vendors can enjoy the existing large market share because there is a significant increase in the number of visitors to Suwuk Beach over the past four years (see Table 2).

Meanwhile Gdr or gender variable in trading business in the informal sector did not have a significant effect. It is arguably that the role of male street vendors in the informal sector was greater than the role of female street vendors. Unlike Female Street vendors, male street vendors did not have jobs outside the business, such as taking care of households, thus male street vendors were able to obtain greater business income. However, the regression estimation results indicated that gender did not have a significant effect on the differences in income level, both in male and female street vendors. So it means that there is no difference in the influence of gender on income. In addition, education level variable did not have a significant effect on the differences in income level of street vendors at Suwuk Beach. This finding is consistent with the result obtained by Unger et al (2011), that what distinguishes the level of income between street vendors is the skill or expertise (task-related human capital that is shown by positive and significant effect of variable business owner experiences Exp), and not education level.

\section{CONCLUSION}

This study aimed to find out the factors affecting income level of street vendors, especially those selling foods and beverages at the tourist attraction of Suwuk Beach, Kebumen Regency. We found that the variation in income levels among street vendors can be explained by differences in initial capital, number of workers, and length of business. While based on the estimation results, the variables of gender and education level of street vendors were not determinants in the difference in the income level of street vendors. Thus, in order to improve the welfare of street vendors at the tourist attraction of Suwuk Beach, Kebumen Regency, the local government should increase access to capital sources for street vendors and improve the skills or expertise of street vendors or workers in carrying out their business. 


\section{REFERENCES}

Adhikari, D. B. (2011). Income Generation in Informal Sector: A Case Study of The Street Vendors of Kathmandu Metropolitan City. Economic Journal of Development Issues, 13, 1-14.

Adhikari, D. B. (2017). Informal Street Food Trade: A Source of Income Generation in Urban Nepal. Economic Journal of Development Issues, 23(1-2), 1-17.

Antara, I. A., \& Aswitari, L. P. (2016). Beberapa Faktor Yang Mempengaruhi Pendapatan Pedagang Kaki Lima di Kecamatan Denpasar Barat . E-Journal Ekonomi Pembangunan, 5, 1168-1346.

Disporawisata. (2017). Statistik Kepariwisataan Kebumen 2017. Kebumen: Dinas Kepemudaan dan Olahraga dan Pariwisata Kabupaten Kebumen.

Harahap, E. F. (2017). Analysis of Determinants of Income and Efforts to Improve the Welfare of Street Vendors in Padang City. European Journal of Business and Management, 9 (3), 118-124.

Otto, M., Fulton, J., Ibro, G., \& Deboer, J. L. (2011). Women Entrepreneurship in West Africa: The Cowpea Street Food Sector in Niger and Ghana. Journal of Developmental Entrepreneurship, 16(1), 37-63.

Tedd, L., Chowdhury, N. A., \& Liyanarachchi, S. (2001). Energy and Street Food Vendors. Boiling Point, 10-12.

Ulyssea, G. (2010). Regulation of Entry, Labor Market Institutions and The Informal Sector Regulation of Entry, Labor Market Institutions and The Informal Sector. Journal of Development Economics, 91(1), 87-99.

Unger, J. M., Rauch, A., Frese, M., \& Rosenbusch, N. (2011). Human Capital and Entrepreneurial Success: A Meta-Analytical Review. Journal of Business Venturing, 26, 341-358. 